\title{
FISIOTERAPI PADA KASUS CEREBRAL PALSY
}

\author{
Mila Amelia Sopandi ${ }^{1 \%} ;$ Nesi $^{2}$ \\ 1) milaameliasopandi@gmail.com, Politeknik Kesehatan Hermina \\ 2) nesiaureole@gmail.com, Politeknik Kesehatan Hermina \\ *penulis korespondensi
}

\begin{abstract}
Cerebral palsy is a condition of damage to brain tissue in the motor center or its connecting networks, which occurs during prenatal, childbirth or the process of forming the central nervous system, characterized by paralysis, paresis, impaired coordination or motor function abnormalities. Cerebral palsy can be caused by babies born prematurely, mothers contracting the virus during pregnancy, trauma during birth. Because the brain damage he experienced will affect the system causing poor coordination, poor balance, abnormal movement patterns. This journal aims to explain about physiotherapy in cases of cerebral palsy. The research method used is descriptive qualitative with retrieval of material based on literature review. The results showed that giving Neurosensomotor Reflex Integration and Neuro Development Treatment (NDT) can improve postural tone, change abnormal patterns, teach motor skill patterns and develop basic movement patterns.
\end{abstract}

Keywords: cerebral palsy; Neurosensomotor Reflex Integration; Neuro Development Treatment (NDT).

\begin{abstract}
Abstrak
Cerebral palsy merupakan suatu kondisi kerusakan jaringan otak pada pusat motorik atau jaringan penghubungnya, yang terjadi pada selama prenatal, persalinan atau proses pembentukan syaraf pusat, ditandai dengan adanya paralisis, paresis, gangguan kordinasi atau kelainan fungsi motorik. Cerebral palsy dapat disebabkan oleh bayi lahir prematur, ibu terjangkit virus selama masa kehamilan, terjadinya trauma selama lahir. Karena kerusakan otak yang dialaminya akan mempengaruhi sistem sehingga menyebabkan koordinasi yang buruk, kesimbangan yang buruk, pola gerakan yang abnomal. Jurnal ini bertujuan untuk menjelaskan tentang fisioterapi pada kasus cerebral pasly. Metode penelitian yang digunakan deskriptif kualitatif dengan pengambilan materi berbasis literatur rivew. Hasil penelitian menunjukan bahwa pemberian Neurosensomotor Reflex Integration dan Neuro DevelopmentTreatment (NDT) dapat memperbaiki tonus postural, merubah pola-pola abnormal, mengajarkan pola-pola motorskill dan mengembangkan pola-pola gerakan dasar.
\end{abstract}

Kata kunci : cerebral palsy; Neurosensomotor Reflex Integration; Neuro DevelopmentTreatment (NDT).

\section{PENDAHULUAN}

Di negara kita ini masih banyak anak anak yang terlahir dengan keadaan disabilias. Anak dengan disabilitas umumnya dipandang sebelah mata oleh orang lain. Anak dengan disabilitas memiliki berbagai keterbatasan dalam kemampuan fisik, mental, sosial, adaptasi, kemandirian, dan kesulitan dalam pemenuhan kebutuhan sehari-hari. Hal ini didukung oleh penelitian yang dilakukan Geniofam (2010) menyatakan bahwa anak berkebutuhan khusus menunjukkan padaketidakmampuan mental, emosi atau fisik. Berdasarkan data Badan Pusat Statistik (BPS) tahun 2017, menemukan bahwa terdapat 1,6juta anak di Indonesia Berkebutuhan Khusus (ABK).

Salah satu kasus contoh disabilitas pada anak yaitu cerebral palsy. Cerebral palsy adalah suatu kondisi kerusakan jaringan otak pada pusat motorik atau jaringan penghubungnya, yang terjadi pada selama prenatal, persalinan atau proses pembentukan syaraf pusat, ditandai dengan adanya paralisis, paresis, gangguan kordinasiatau kelainan kelainan fungsi motorik (Hendri Eliyanto, 2013).

\section{METODE}

Metode penelitian ini menggunakan deskriptif kualiatif dengan pengambilan materi berbasis literatur rivew. Artikel yang digunakan pada penelitian ini diperoleh dari google scholar. 


\section{HASIL DAN PEMBAHASAN \\ Etiologi}

Kondisi Cerebral palsy umumnya diikuti dengan gangguan medis lainnya, antara lain yangmental retardasi, kejang atau epilepsi, masalah pertumbuhan dan perkembangan, gangguan penglihatan dan pendengaran, serta gangguan sensasi dan persepsi. Pada kondisi cerebral palsy, terjadi mental retardasi yang bervariasi dari yang ringan, sedang dan berat. Meskipun demikian, terdapat seperti anak dengan cerebral palsy tanpa diikuti mental retardasi. Gangguan medis lainnya yaitu kejang atau epilepsi. Jenis epilepsi dapat bervariasi, bisa berupa kejang umum maupun kejang parsial. Gangguan ketiga yaitu masalah pertumbuhan dan perkembangan dengan derajat gangguan ringan sampai berat. Gangguan keempat yaitu gangguan pendengaran dan penglihatan, anak dengan kondisi cerebral palsy umumya mengalami strabismus atau hemianopia. Gangguan terakhir yaitu sensasi dan persepsi abnormal. Kondisi cerebral palsy dapat menyebabkan seseorang mengalami gangguan dalam merasakan sensasi, kesulitan mengidentifikasi obyek dengan meraba (stereognosia), sehingga menyebabkan mereka mengalami kesulitan dalam mengidentifikasi suatu obyek jika tidak melihat obyek tersebut (Parenting Indonesia, 2021).

\section{Insiden dan Prevalensi}

Terdapat 17 juta orang dengan kondisi cerebral palsy tersebar di seluruh dunia (worldcpday,2019). Berdsarkan Susenas BPS RI (2012), tercatat sebanyak 532.130 anak menderita CP atau sekitar 0,6\% dari jumlah seluruh anak (WD F. V., 2016). Hasil survei riset kesehatan dasar (Riskesdas) tahun 2012, menunjukkan jumlah kasus cerebral palsy pada anak usia 24-59 bulan adalah 0,09\% dari jumlah keseluruhan penduduk Indonesia dengan usia yang sama (Infodatin,2014).

\section{Manifestasi Klinis}

Selain mengalami gangguan fungsi motorik dan koordinasi, anak dengan kondisi cerebral palsy juga bisa mengalami berbagai gangguan penyerta, misalnya gangguan menelan, gangguan kognitif, kejang, gangguan pendengaran dan penglihatan dan gangguan sensasidan presepsi (Eliyanto \& Hendriani, 2013). Anak dengan cerebral palsy memiliki kelemahan dalam mengendalikan otot pada tenggorokkan, mulut, dan lidah yang menyebabkan anak dengan kondisi cerebral palsy tampak selalu berliur, kesulitan makan, dan menelan (Maimunah, Siti, 2013).

\section{Intervensi Fisioterapi}

Cerebral palsy tidak bisa disembuhkan dengan obat, tetapi dengan metode terapi dan teknologi yang dapat membatu anak dengan kondisi cerebral palsy bertahan hidup, seperti kursi roda, penyangga kaki, kawat gigi, dan lainnya (Eliyanto \& Hendriani, 2013;Maimunah, 2013; Listiani \& Savira, 2015). Dengan adanya penanganan fisioterapikualitas gross motor anak dengan cerebral palsy dapat semakin baik dan akhirnya dapat menigkatkan kualitas hidupnya.

Fisioterapi merupakan bentuk pelayanan kesehatan yang ditunjukan kepada individu dan atau kelompok untuk mengembangkan, memelihara, dan memulihkan gerak dan fungsi tubuh sepanjang rentang kehidupan dengan menggunakan penangganan secara manual, peningkatan gerak, peralatan (fisik, elektroterapeutis dan mekanisme) pelatihan fungsi, komunikasi (Ikatan Fisioterapi Indonesia, 2016). Sesuai dengan definisinya fisioterapi membantu mengembangkan dan memelihara gerak dan fungsi motorik anak dengan cerebral pals.

Pada kondisi cerebral palsy, permasalahan yang terjadi adalah gangguan postural control dan motor control akibat adanya lesi pada otak yang sedang tumbuh biasanya ditandai dengan gangguan keseimbangan dan hipotonus atau hipertonus postural. Pada kasus cerebral 
palsy fisioterapi dapat melakukan dengan cara memberikan Neurosensomotor Reflex Integration sebagai mempersiapkan awal otot untuk sebelum modulasi motorik dan meningkatkan kemampuan kerja fungsional motorik anak, dengan keterlambatan perkembangan saraf dan Neuro Development Treatment (NDT) sebagai normalisasi tonusotot, peregangan, 3 penentuan posisi, perbaikan, dan koreksi postur (Masgutova, svetlana, 2018).

Neurosensomotor Reflek Integrasi merupakan metode yang memfokuskan pada mekanisme perkembangan dan pembelajaran gerakan secara natural (Rentschler et all., 2008). Neuro Development Treatment (NDT) merupakan suatu prinsip untuk memperbaiki dan mencegah postur dan pola gerakkan abnormal, serta mengajarkan postur dan pola gerakkan yang normal. Tujuannya NDT untuk memperbaiki tonus postural, untuk mengkembaikan kualitas tonus normal serta untuk mempermudah gerakkan yang disadari. Sehingga NDT pada anak cerebral palsy efektif dalam meningkatkan kekuatan otot serta meningkatkan kemampuan kemampuan fungsional. NDT juga dapat memfasilitasi yaitu upaya untuk mempermudah reaksi-reaksi otomatis dan gerakkan yang baik

Selain itu, fisioterapi memberikan latihan berupa gerakan re-patterning (belajar kembali dan skema re-coding). gerakan re-patterning berfokus pada pengulangan refleks dinamis dan postural dengan menghidupkan kembali memori motorik genetik dan mengaktifkan mekanisme defensif di otak-tubuh-sistem. Peningkatan koordinasi antara neurologis bawaan, sensorik, dan komponen motorik yang menyediakan fondasi dimana gerakan reflek terintegrasi dengan gerakan yang disengaja, keterampilan motorik yang dipelajari dan kemampuan motorik yang dikendalikan secara sadar pada anak dengan kondisi cerebral palsy. Teknik re-patterning dan relaksasi untuk membangkitkan memori motorik genetik latern di batang otak, sehingga untuk pengembangan saraf

Manfaat spesifik penanganan fisioterapi pada cerebral palsy yaitu menurunkan hipertonus dan spastisitas menaikkan tonus otot dalam flaksid, atethoid dan ataxia, merubah pola-pola sikap abnormal anak cerebral palsy, mengajarkan pola-pola motor skill, mengembangkan pola-pola gerakan dasar (Zuyina Luk, Lukaningsih, 2010).

Pada cerebral palsy terjadi kerusakan di otak sehingga tidak bisa disembuhkan atau dengan kata lain bersifat permanen. Meskipun demikian, penanganan fisioterapi dapat membantu mempertahankan dan meningkatkan fungsi gerak pada tubuh. Jika dibiarkan begitu saja dan tidak segera ditangani oleh fisioterapi maka anak akan mengalamibeberapa kesulitan dalam motoric kasar, menjaga keseimbangan dan pola jalan yang benar,kelemahan otot- otot jantung dan paru, kontraktur otot, kekaukan sendi, skoliosis, memperburuk postur tubuh (Budi, Hardiman, 2013).

Untuk menangani kasus cerebral palsy, fisioterapi umumnya bekerjasama/berkolaborasi dengan tenaga kesehatan lainnya yaitu dokter spesialis, psikolog, okupasi terapi, terapi wicara, orthotic dan prostetic, neurologi, ortopedi, psikiatri (Ikatan Fisioterapi, 2016). Dengan kerjasama dari berbagai bidang ilmu diharapkan anak dengan cerebral palsy mengalami perbaikan kualitas hidup dan lebih mandiri (Ikatan fisioterapi, 2016).

\section{PENUTUP}

Berdasarkan uraian diatas dapat disimpulkan bahwa Cerebral palsy merupakan sebuah kondisi yang menyerang pada otak yang mempengaruhi berbagai aspek kehidupan anak terutama dalam kemampuan fisik, sosial, mental, kemandirian, adaptasi, dan kesulitan dalam pemenuhan kebutuhan sehari-hari. Anak dengan cerebral palsy mengalami gangguan utama fungsi motorik dan koordinasi. Penanganan fisioterapi padacerebral palsy dapat melakukan Neurosensomotor Reflex Integration dan Neuro DevelopmentTreatment (NDT). Manfaat dari penanganan fisioterapi pada cerebral palsy yaitu memperbaiki tonus postural, merubah pola- 


\section{Indonesian Journal of Health Science}

Volume 1 No. 2, Desember 2021

pola abnormal, mengajarkan pola-pola motor skill dan mengembangkan pola-pola gerakan dasar.

\section{DAFTAR PUSTAKA}

Eliyanto, H., \& Hendriani, W. (2013). Hubungan Kecerdasan Emosi dengan Penerimaan Ibu Terhadap Anak Kandung yang Mengalami Cerebral Palsy.Jurnal Psikologi dan Perkembangan Vol.2 No. 2, 124-130.

Anindita, R. A., Apsari, C. N. (2019). Pelaksanaan Support Group Pada OrangtuaAnak Dengan Cerebral Palsy. Jurnal Pekerjaan Sosial Vol. 2 No: 2

Rentschler, M., Ed, M., Method, M., \& Specialist, I. (2008). The Masgutova Method of Neuro-Sensory-Motor and Reflex Integration: Key to Health, Development and Learning, (202).

Rahim, F. (2018). Penatalaksaan Fisioterapi Pada Cerebral Palsy Spastik Quadripelgi.

Masgutova, S., Russia-poland, P. D., Wenberg, E. S., \& Retschler, M. (2008). MasgutovaMethod of Reflex Integration for Children With Cerebral Palsy, 1-23.

Adam RD, Victor M. (1981). Normal Development dan Deviation in Development of The Nervous System. Principles of Neurology. 2 nd edition. New York : Mc Graw Hill Book Co. 387 - 412.

Maimunah, S. (2013). Studi Eksploratif Perilaku Koping Pada Individu Dengan Cerebral Palsy. Jurnal Imliah Psikologi Terapan Vol. 1 No. 1, 156-171.

Ikatan fisoterapi indonesai. (2016).

Anindita, A. R. \& Apsari, N. C. (2019). Pelaksanaan Support Group PadaOrangtua Anak Dengan Cerebral Palsy. Page 4.

World cerebral palsy day october 6. diakses pada minggu 26 mei 2019. (https://worldcpday.org/). Mengunjungi 28 desember 2020

Lukaningsih, Zuyina Luk. (2010). Pengembangan Kepribadian. Yogyakarta: Mulia Medika.

Hardiman, B. (2013). Penatalaksanaa Fsiaioterapi Pada Kasus Cerebral PalsyQuadriplegi Dengan Metode Neuro Develpoment Treatment ( NDT)

Parenting Indonesia. Gangguan Medis Penyerta Cerebral Palsy. (https://www.parenting.co.id/bayi/gangguan+medis+penyerta+cerebral+palsy).

Mengunjungi blogspot 02 Januari 2021 Infodation. Hari Penyandang Cacat Sedunia. 2014.

(http://www.kemkes.go.id/download.php?file=download/pusdatin/infodatin/in fodatin_disabilitas.pdf). Mengunjungi 04 Januari 2021 